\title{
The Ethics of Human Intervention on Behalf of 'Others'
}

I regularly pass several homeless persons surviving on the streets even in winter. One sits on a folded scrap of a blanket leaning against a wall looking thin, pale and resigned, doing some calligraphy of messages on card for those who want them. Almost everyone walks quickly past, some manoeuvring to the opposite side of the wide pavement, others almost treading on some of their sparse belongings. Hardly anyone makes eye contact. The harsh reality of living on the street is some days without enough food and basic provisions. Christmas produces a spike of concern and generosity that vanishes immediately afterwards. Advice issued by the local authorities and charities cautions against giving money, on the basis of characterising all street people as substance abusers. Since the rise of Thatcherist meritocracy and neoliberalism, homelessness, living and dying on the streets has become rife in the UK. This policy failure suggests a moral obligation on 'witnesses' to help, to prevent or reduce suffering, but what interventions on what basis? A recent newspaper article by a once homeless person (Lavelle, 2019) offers sobering simple guidance to those who wish to help, and that includes talking and engaging with those suffering. Sympathy and engagement seem hard enough with other humans, but they at least have the potential to directly express their concerns and communicate, while there are many who remain effectively silent - such as children, future generations and non-humans.

In environmental ethics strong themes have been to debate human obligations toward the last of these groups and Nature more generally. Arguments are put forward for moral status of sentient beings as well as other non-human organisms and entities (such as rivers or lakes) in decision-making and seeking to enable flourishing and enforce rights. This raises the problem of how intervention should be undertaken when rights or flourishing-potential of different morally considerable subjects conflict. The major alternative, consequentialist reasoning, has its own problems such as reduction of values to utilitarian pain and pleasure principles. More generally, in this materialist managerial age, there are concerns over objectification of the other and excessive technocratic 'solutions' that pay little attention to the constituent values of 'others' and their autonomy.

This issue of Environmental Values concerns a range of arguments about what is appropriate intervention on the behalf of non-human 'others'. According to the Intergovernmental Science-Policy Platform on Biodiversity and Ecosystem Services (IPBES, 2019) the top three drivers for biodiversity loss are: (i) changes in land and sea use; (ii) direct exploitation of organisms; and (iii) accelerated climate change. These human-induced factors involve a complex web of interests, interactions, dependencies and different levels of 


\section{EDITORIAL}

overt or obscure powers. Criticism of 'business as usual' and 'sloppy' or manipulative democracy call for systemic political change (e.g. Machin, 2019). Any progress along such 'new' trajectories may help alleviate millennials' deep-seated angst about environmental thresholds being surpassed, and their frustration about not seeing policies and actions to secure their future from world leaders and decision-makers. However, it is open to debate how non-anthropocentric perspectives should be taken into account, or what interventions on behalf of non-human others are justified and on what basis.

The core principle of non-anthropocentric ethics is to extend moral standing to non-humans such as animals, plants and landscapes. American Pragmatists Ben Minteer and Bryan Norton have argued that non-anthropocentric viewpoints, as expressed by J. Baird Callicott, Eric Katz, Holmes Rolston III and Laura Westra, are anti-democratic. Mark Alan Michael unpacks and responds to this pragmatist position. He identifies three specific claims that are made about non-anthropocentrists by their pragmatist critics: (1) that they know the political truth; (2) that anyone disagreeing with their basic principle should be excluded from policy discussions; and (3) that their basic principle is selfevident. Quoting key passages from the work of Norton and Minteer, Michael deconstructs each of these characterisations of non-anthropocentrists.

Claim (1) is clarified by Michael's differentiation between political truths, which, drawing on David Copp's 'political truth principle', means convincing responses to the question of 'What society ought to do?', and political authority, which involves matters of fairness and equality of the political system. Michael argues that to think that political truth exists and that non-anthropocentrists may put a claim on such truth does not equate with making claims of where political authority should lie. Claim (2) is clarified by Michael's distinction between political context (PC) and epistemic context (EC) when making policy. Here, decision-making rules and any constraints on deliberation are subject to answering how political authority is to be justified (Michael, 2020: 17-18). Decisions may fail to reflect political truth, ${ }^{1}$ but this is the price of the democratic process with fair and equal treatment of voters. That said, striving for truth and debate to elicit political truth are seen as prime concerns that constitute the 'epistemic context'. Policies and positions that are deemed to fail under scrutiny can and should be rejected, and this is consistent with democratic process. Claim (3) considers the question of whether the basic moral anthropocentric principle is self-evidently true. Michael explains that the issue here is not about whether the claim to moral superiority is true but whether it is self-evident. He then argues that if a basic principle being self-evident can be debated and supported by reasoned argument, then the charge of being antidemocratic is misplaced.

1. The term 'political truth' is not further unpacked in the article beyond introducing David Copp's 'political truth principle'; key here is that a moral realist perspective claims that truths, about what society ought to do, exist. 
Continuing the theme of the moral considerablilty of the non-human, Kyle Johannsen argues for large-scale human interventions in nature on the basis that negative duties (e.g. preventing harm) trump positive duties (doing good). In particular, well intentioned action to reduce wild animal suffering should not be prevented due to uncertainty or fallibility. Evolutionary and ecological knowledge informs Johannsen's explanation and the rationale for fallibilityconstrained interventions. The theory of r-Strategy and K-Strategy species provides an example (without necessarily endorsing the theory). The r-strategy species are those that produce a lot of young, most of which perish in relatively harsh or predatory circumstances, whereas K-strategy species produce few offspring, and tend to closely protect and rear them. Based on the observation that most wild animals tend to be r-Strategists whose young largely live short painful lives, a three-step argument is constructed which leads to the conclusion that: 'Most sentient individuals born into the world do not live flourishing lives, and their lives may not be worth living' (Johannsen, 2020: 4). Some suggested interventions to reduce suffering relate to gene editing to modify r-Strategists to become more like K-Strategists. This is similar to the argument by Rohwer (2018) for cognitively enhancing animals, such as native Australian marsupials, that are currently deemed to be ill-equipped to identify introduced predatory species (e.g. feral cats and red foxes) which is then given as the primary reason for their massive decline, and some extinction, over the past 200 years. Johannsen (2020: 34) then criticises two specific positions: 'first, a cautious attitude toward intervention doesn't take wild animal suffering seriously enough' and 'second, even a cautious attitude toward intervention is reckless'.

The ethical basis for intervention is also addressed by Andrew McCumber and Zachary King's article, which provides a very topical discourse analysis of ecologically informed policy and social media responses relating to the 'Thomas Fire' event in California in 2017. Its relevance and context go well beyond wildfires, highlighting emerging 'radical transformations' of social-ecological connections due to emergencies caused by human action that threatens the flourishing and survival of wild animals. The authors make a compelling case for easing tensions between polarised domains: between 'interventionist' and 'non-interventionist' stances to the assisting of wild animals during disasters; and between micro-level human concern for and interaction with wildlife and macro-ecological perspectives reflected in formal wildlife policies and advice.

McCumber and King highlight that non-intervention advice on helping wild animals in urban contexts is usually regarded as rational (to keep wild animals wild and not make them dependent on humans), but the same could be said for temporary interventions by humans when helping wild animals access water and migrate to new habitats after a devastating fire. Increasing encroachment and deterioration caused by humans directly (e.g. new development and land 


\section{EDITORIAL}

use change) and indirectly (e.g. pollution and climate change) produce environmental injustices and disasters in-waiting. Official policies and advice may thus have to adjust to help prevent further loss and damage and secure support to maintain habitats and populations of wildlife species. This also connects the micro-level, such as individual/neighbourhood/local scale action, with macroscale ecological management. In McCumber and King's own words, we need 'a more critical and holistic approach to social responsibility and environmental issues' where 'our affective, personal relations to the nonhuman world [...] may stimulate environmental concern in the first place' (p. 49). The results from the in-depth discourse analysis, along with their (re-)conceptualisation of human assistance to (wild) animals in the context of the Anthropocene, provides some interesting parallels with how human actions change the ability of wildlife to cope (as referred to above in relation to Johannsen's article) and questions the assumption that nature can always take care of itself.

Christian Hunold's article also focuses on human-wildlife relations in an urban environment and particular wild species that adopt urban areas as their habitat. This is a phenomenon that is probably increasing due to urban greening measures and deterioration of 'rural' wildlife habitats. Philadelphia is used for a case study which analyses fifteen urban greening professionals' perceptions and practices in response to animal occurrences in the urban environment. Hunold identified three distinct frames for how these practitioners relate to urban wildlife, namely in terms of animal control, public health and biodiversity. A key question, and food for thought for city planning, is 'whether cities teeming with wildlife are also becoming cities for wildlife, not just materially but also ontologically, in the sense that the needs of wild animals are actively accommodated in policy and design' (p. 69). Another poignant question is whether we need to let go of a focus on 'private' and 'human' spaces that optimise environments for human purposes and instead better account for ecological needs and thus adopt ecological design principles and policies that factor both human and wildlife needs into urban planning. Hunold reports that 'biodiversity-oriented framing of urban planning has had little influence on municipal policy' (p. 83). The considerations in this article go far beyond the specifics of Philadelphia with implications for all urban 'development'.

Hunold's line of argument steers towards a holistic approach that argues for peaceful human-wildlife coexistence, where the urban/nature dualism is no longer seen as creating exclusive realms that emphasise human-wildlife conflict, but where instead connection with nature is seen as advantageous for human health and well-being (even though the conflation of human and nature realities is contentious, see e.g. Pollini, 2013). Some enforcement of boundaries between human and wildlife would still be necessary (such as keeping wildlife species that are regarded as 'pests' out of buildings), but overall having more wildlife in cities is argued to be beneficial for public health as well as biodiversity. That said, the questions of what 'wild animals' and 'wildlife' 
this targets or includes and where lines would be drawn in urban planning and greenspace design are not explicitly discussed beyond the case study.

These ideas link to themes recently discussed by others in Environmental Values. While some urban greening aims to attract wild animals, urban areas have also become a test-bed for technology-infused complex human-nature 'hybrid' situations linked to technologising nature and naturalising technology as part of urban design and planning - as, for example, discussed by HołyŁuczaj and Blok (2019). This raises issues around anthropomorphising nature and in so doing affecting its autonomy. It also highlights some of the tensions in rewilding efforts, even when aimed at rural rather than urban areas (see, for example, the discussion of the case of the Cambrian Wildwood in Wales by Wynne-Jones et al., 2018). Drenthen (2005: 333) helpfully points to the human dilemma of valuing wildlife and wilderness precisely because it is 'something radically other ... which both has to and cannot be properly appropriated', and this theme is also dealt with by Gammon (2018) and other articles in the Environmental Values 27(4) special issue on 'Rewilding in Cultural Layered Landscapes'.

The final article in this issue takes the reader back to scrutinising what we actually mean by wilderness and how the concept is defined and applied at a time when human interference has seemingly spread across the globe. Joshua Duclos focuses on four objections - empirical, cultural/racial, philosophical and environmental - because he believes the idea of 'wilderness' needs uncomplicating, sifting out 'misguided, irrelevant, and inaccurate' objections (p. 105). Debating the usefulness and meaning of 'wilderness' is in his view worthwhile.

In response to the empirical objection Duclos argues that 'wilderness' can be regarded as a relative rather than an absolute concept, where 'purity' is the relative absence of human activity and influence rather than an area totally devoid of any cultural imprint or human impact. He exemplifies this with a string of comparisons, where the degree of wilderness is shown to be greater than $(>)$ another: Alaskan National Wildlife Refuge $>$ Walden Pond $>$ Boston Common $>$ Logan Airport. The cultural, ethnic and racial objections relate to 'Western ethnocentrism, racial insensitivity, and cultural myopia' (p. 94) which Duclos acknowledges do exist, e.g. in relation to some cultural bias in motivations to preserve or restore species, habitats or wilderness; and furthermore the existence of cultural and scientific arrogance. In response to these objections, Duclos sees the crux of the matter as distinguishing between the evaluative and the factual and focusing on scrutiny and transparency to avoid scientificor otherwise-derived myths or inaccuracies. With regard to the philosophical objection (which concerns an untenable human-nature dualism), Duclos once again acknowledges its partial truth, but in response highlights the existence of critical differences between humans (and human culture) and (wild) nature. Finally, tackling the environmental objection which centres around the need 


\section{EDITORIAL}

for environmental action rather than philosophical debate, Duclos argues that philosophical debates have strengthened the rationale for and motivated environment action even though 'philosophy is not - and should not be - activism' (p. 104).

The ethics of human intervention on behalf of others shows a plurality of arguments and wide range of influential thinkers and calls for policy change and human action. I found the articles in this issue an interesting continuation and extension of other recent discussions in this journal, and especially issues 27(2), 27(4) and 28(3), as partly reflected in the comments and references mentioned above. In an editorial for Environmental Values Marion Hourdequin writes about foregrounding change and opening up 'new ways of conceiving and acting in relation to nature' (2018: 116), which could help bridge the policy-action/implementation gap. The papers by McCumber and King (2020) and Hunold (2020) also contribute to that. Kaaronen (2018: 179) writes about 'drawing an ontological bridge between humans and nature' and 'providing a coherent philosophical basis ... for policy making', and the papers by Michael (2020), Johannsen (2020) and Duclos (2020) raise important points for debate. In an age in which human systems create unforeseen impacts that have become the major concern for humans and non-humans alike, the role of intervention on behalf of others requires serious reflection and an ethical foundation.

\section{CLAUDIA CARTER Birmingham City University}

\section{REFERENCES}

Drenthen, M. 2005. 'Wildness as a critical border concept: Nietzsche and the debate on wilderness restoration'. Environmental Values 14(3): 317-337. Crossref

Duclos, J.S. 2020. 'Uncomplicating the idea of wilderness'. Environmental Values 29(1): 89-107. Crossref

Gammon, A.R. 2018. 'The many meanings of rewilding: An introduction and the case for a broad conceptualisation'. Environmental Values 27(4): 331-350. Crossref

Hoły-Łuczaj, M. and V. Blok. 2019 'Towards a philosophy of technology and environmental philosophy 2.0'. Environmental Values 28(3): 325-345. Crossref

Hourdequin, M. 2018. 'Varieties of non-anthropocentrism: Duty, beauty, knowledge and reality'. Environmental Values 27(2): 113-118. Crossref

Hunold, C. 2020. 'Urban greening and human $\neq$ wildlife relations in Philadelphia: From animal control to multi-species coexistence?' Environmental Values 29(1): 67-87. Crossref

IPBES. 2019. Summary for policymakers of the global assessment report on biodiversity and ecosystem services of the Intergovernmental Science-Policy Platform on Biodiversity and Ecosystem Services. IPBES secretariat, Bonn, Germany. Advanced unedited version 6 May 2019. https://ipbes.net/global-assessment 


\section{EDITORIAL}

Johannsen, K. 2020. 'To assist or not to assist? Assessing the potential moral costs of humanitarian intervention in Nature'. Environmental Values 29(1): 29-45. Crossref

Kaaronen, R.O. 2018. 'Reframing tacit human-nature relations: An inquiry into process philosophy and the philosophy of Michel Polanyi'. Environmental Values 27(2): 179-201. Crossref

Lavelle, D. 2019. 'Homelessness is now part of all our lives. Here's what you can do to help'. The Guardian 24 September 2019. https://www.theguardian.com/cities/2019/ sep/24/homelessness-is-now-part-of-all-our-lives-heres-what-you-can-do-to-help

Machin, A. 2019. 'Democracy and agonism in the Anthropocene: The Challenges of knowledge, time and boundary'. Environmental Values 28(3): 325-345. Crossref

McCumber, A. and Z. King. 2020. 'The wild in fire: Human aid to wildlife in the disasters of the Anthropocene.' Environmental Values 29(1): 47-66. Crossref

Michael, M.A. 2020. 'Is nonanthropocentrism anti-democratic?'. Environmental Values 29(1): 9-28. Crossref

Pollini, J., 2013. 'Bruno Latour and the ontological dissolution of nature in the social sciences: A critical review'. Environmental Values 22(1): 25--42. Crossref

Rohwer, Y. 2018. 'A duty to cognitively enhance animals'. Environmental Values 27(2): 137-158. Crossref

Wynne-Jones, S., G. Strouts and G. Holmes. 2018. 'Abandoning or reimagining a cultural heartland? Understanding and responding to rewilding conflicts in Wales: The case of the Cambrian Wildwood'. Environmental Values 27(4): 377-403. Crossref 
